\title{
AMBUSH MARKETING VS. OFFICIAL SPONSORSHIP: IS THE INTERNATIONAL I.P. AN UNFAIR COMPETITION REGIME A GOOD REFEREE?
}

\begin{abstract}
DIEGO PARDO AMÉZQUITA*
Imagine you throw a party and invite heaps of brilliant, interesting people. Imagine your roommate fails to help with the planning or the cost. Imagine the night of the party, your deadbeat roomie shows up and claims co-sponsorship. Imagine watching in awe as the freeloader takes credit for your expenses and effort. Now imagine that party just cost you $\$ 20 M$.
\end{abstract}

A. D. Sauer ${ }^{1}$

The 1984 Summer Olympic Games held in Los Angeles have been -and will continue to be- remembered for footage from Swiss athlete Gabriela AndersenSchiess's dramatic struggle to finish the women's marathon. She refused medical assistance to avoid disqualification, despite showing heat exhaustion symptoms, right leg limping and left arm cramps. Her truly admirable feat drew the attention of a horrorized crowd that cheered her as she limped to the finish line, and has therefore been branded as a symbol of human determination for competitive achievement through one's own efforts. However, those Olympiads have also been branded as the birthplace of another type of off-field competition of efforts that has drawn the public's attention and led firms to compete amongst them ever since: The one between official sponsorship and ambush marketing of large scale events.

\footnotetext{
* Lawyer (LL.B) from Universidad de los Andes (2009, Bogotá, D.C., Colombia). Llm in Intellectual Property, University of Turin, Italy, and the World Intellectual Property Organization (2015, Turin, Italy). Specialization Diploma on Public Law (2012) and Competition Law (2014) from Universidad Externado de Colombia. diegopardo18@ hotmail.com Fecha de recepción: 2 de enero de 2016. Fecha de aceptación: 27 de julio de 2016. Para citar el artículo: Pardo Amézquita, D. Ambush Marketing vs. Official Sponsorship: Is the International I.P. an Unfair Competition Regime a Good Referee? Revista La Propiedad Inmaterial n. ${ }^{\circ}$ 21, Universidad Externado de Colombia, enero-junio 2016, pp. 5-24. DOI: http://dx.doi.org/10.18601/16571959.n21.01

1. Sauer, A. D. Ambush Marketing: Steals the Show. Brandchannel. Retrieved on December 2014, from: [www.brandchannel.com/features_effect.asp?pf_id=98].
} 
This paper will address the problem of why and to which extent must ambush marketing be contrasted, provided that it is a practice that ordinary intellectual property and competition law has been unable to deter, and that extraordinary measures are difficult to adopt at an international level. This difficulty jeopardizes the interest for official sponsoring of major events, and the events themselves. For this purpose, this paper will (i) briefly examine the intersection between intellectual property rights and the business of sports, in order to (ii) encase ambush marketing as a controversial -yet not necessarily illegal- business practice that exploits another's commercial effort and deflects attention from official sponsorship of major events. It will then present (iii) the traditional and extraordinary legal responses to these practices, and the issues and difficulties that they raise, to finally conclude that (iv) there is an urgent need to harmonize, at an international level, the legality -or not- of the matter, regardless of (v) the inherent ambush marketing paradoxes.

\section{The Intersection of Intellectual}

\section{Property Rights and the Business of Sports}

It is an undeniable fact that for many years now, sports -as old as mankind- are no longer confined to mere hobbies, recreational activities or carrier choices. They are now huge business opportunities and large scale events of gigantic commercial importance. With a total of over 4.7 billion viewers -or nearly $70 \%$ of the world's population- of the 2008 Beijing Olympics ${ }^{2}, 3.6$ billon viewers in the 2012 London Olympics $^{3}$, or the 3.2 billon viewers of the 2010 FIFA World Cup held in South Africa and the 3.4 billon viewers expected for the 2014 World Cup edition in held in Brasil, it comes as no surprise that both the Olympics and the FIFA World Cup are the two biggest multi-day sporting events, each broadcasted to an audience in over 200 countries. Other single-game sporting events such as El Clásico (Barcelona vs. Real Madrid football games) and the annually held Super Bowl (a single game American football championship) draw over 100 million viewers, with the latter's half time show attracting more than 115 million viewers. With such a potential for brand exposure, it is not surprising that a 30-second advertisement spot at the 2014 Super Bowl half time show reached an all time record cost of $\$ 4$ million dollars. And still, Forbes magazine reported that the consensus among industry executives was that

[Advertising at the Super Bowl] is still the best bargain around. Only during the game can advertisers reach an audience transcending individual demographics. With $40 \%$ female viewers and multiple generations represented within the $110+$ million viewers

2. [www.nielsen.com/us/en/insights/news/2008/beijing-olympics-draw-largest-everglobal-tv-audience.html].

3. [www.olympic.org/Documents/IOC_Marketing/London_2012/LR_IOC_MarketingReport_medium_res1.pdf]. 
expected, the game offers marketers a soapbox they can't get during a network drama or even a premium (and costly) event such as an American Idol premierét.

Under these circumstances, some aptly consider this age as the era of corporatization of sports (KalAmadi, 2012). And, as a matter of business, both sponsors and major sporting event organizers are called upon to rely on intellectual property law to protect all the creative elements that come along with carrying out the events, as well as their marketing, broadcasting and licensing activities. By way of example, event names (e.g. "UEFA Champions League", "U.S. Open”, “The Olympics”, etc.) along with their logos, emblems and taglines, and even team names and nicknames (e.g. "Barcelona F.C.", "The All Blacks", "I Rossoneri") hold high commercial value and are significant components of branding and merchandising activities ${ }^{5}$. Trademark law thus becomes essential to safeguard the commercial interests of event organizers and their sponsors by preventing good-will dilution and unauthorized usage of the imagery that may mislead audiences as to the true nature and origin of the event. This is also applicable to domain name protection.

Copyrights and neighboring rights also play a key role in mega-sporting events and their sponsorship. Not only is the artwork in the logos, the literature in promotional material and the merchandise the subject matter of copyrights, but -considering the gigantic audiences drawn by the events- broadcasting rights are broadcaster's warranty to recoup the enormous investment of making these events a truly worldwide affair. It is no surprise then that in sporting events and its promotions, the maximum amount of intellectual property that is created is copyrights ${ }^{6}$.

It is clear then that the commercialization of sports has drawn competition to off-field scenarios in the business world by means of intellectual property exploitation. Sporting event organizers and sponsors will therefore rely on intellectual property law to protect the effort behind the carrying out of the event, and the integrity of the event's commercial potential. The proper exploitation of the intellectual property that is linked to a major sporting event is -along with sponsorship- a conditio sine qua non for both the continuity of the event and its financial success. That is why ambush marketing practices are truly threatening to sporting events.

\section{What is Ambush Marketing?}

The gigantic potential for brand exposure in large scale sporting events such as the Olympic Games or the FIFA World Cup has led firms to venture into exclusive

4. [www.forbes.com/sites/alexkonrad/2013/02/02/even-with-record-prices-10-million-spot/].

5. Kalamadi, S. "Intellectual Property and the Business of Sports Management", in Journal of Intellectual Property Rights, 2012, pp. 437-439.

6. Ibid. 
sponsorship agreements with their organizers, for these are "the most unique, prestigious sporting events, with which a sponsor may wish to identify. Its worldwide audience, relative infrequency, human drama and patriotic overtones making it highly desirable to marketers"

As of 2013, the six FIFA Partners (Adidas, Coca-Cola, Emirates, Hyundai-Kia, Sony and Visa, whose relationship goes beyond the World Cup, covering all major events) were estimated to spend $\$ 730$ million combined for the rights in 2014, having in return the highest level of exposure and exclusive association with FIFA within their product categories. FIFA World Cup Partners (the eight FIFA World Cup Sponsors have rights to the FIFA Confederations Cup and the FIFA World Cup on a global basis) instead, spend an estimated $\$ 500$ million. Although being an official sponsor to a major sporting event requires a huge amount of financial resource, companies expect to create more favourable outcomes, including profit increase, improved stock return and positive advertising effect ${ }^{8}$. Unsurprisingly, the primary reason that companies sponsor events is to fulfil their communication and strategic objectives and to fit their broader marketing strategy, although it is also sometimes used as a defensive strategy to prevent competitors to sponsor the event, and thus enjoy the exposure that comes along with it?

On the event organizers' side, the stakes for having official sponsorship are equally high. Organizing associations, such as FIFA or the International Olympic Committee (IOC) require the sponsorship fees and royalties from licence agreements and intellectual property exploitation for the execution of the event itself ${ }^{10}$. Considering that sponsorship fees are set in an auction-like competition between firms to secure category-exclusive rights of association to the event, their income for event organizers is essential, as hosting them is now an expensive undertaking that needs the support of the private sector: "Without the support of the business community, without its technology, expertise, people, services, products, telecommunications, its financing - the Olympic Games could not and cannot happen. Without this support, the athletes cannot compete and achieve their very best in the world's best sporting event" ${ }^{11}$. Naturally, "A great dependence upon sponsors' funding now primarily exists at international sports events of high-performance sports such as the summer and winter Olympics. Today, international tournaments such as the Football World Cup or the European Championships are also largely dependent on financially strong sponsors" 12 .

7. Louw, A. Ambush Marketing \& the Mega-Event Monopoly. How Laws are Abused to Protect Commercial Rights to Major Sporting Events. T.M.C. Asser Press. The Hague, 2012, pp. 33.

8. KIM, J. W. "The Worth of Sport Event Sponsorship; An Event Study", in Journal of Management and Marketing Research, 2010, p. 2.

9. Johnson, P. Ambush Marketing and Brand Protection: Law and Practice. Oxford University Press, New York City, 2011, p. 5.

10. Nufer, G. Ambush Marketing in Sports: Theory and Practice. Routledge, New York, 2013 , p. 19.

11. Rogge, J. President of International Olympic Committee (2008). Prologue to the Marketing Report Beijing 2008. Lausanne. Retrieved on December 2014 from [www.olympic. org/Documents/Reports/EN/en_report_1428.pdf].

12. Johnson, P. 2008. Op. Cit., p. 5. 
It is clear then a reciprocity between dependence of sponsorship for event organizers, and the brand exposure that large-scale events can provide to firms in terms of marketing and advertisement. But as the benefits associated with sponsorship became evident to marketing departments, its antithesis -ambush marketing-was certain to develop, and its rise is therefore attributed to the increasing sophistication of category-exclusive sponsoring schemes and the massification of sporting events $^{13}$, leading to higher and -in many cases- unreachable sponsorship fees to medium and small enterprises. Crow and Ноек (2003), explain it clearly:

While sponsorship's attractiveness increased, marketers' ability to enter into sponsorship contracts decreased as the cost of securing these and the level of competition for them rose. Ambush marketing thus arose when companies that were formerly able to associate themselves with certain high-profile events (such as the Olympics) became excluded from official sponsorship deals, either by way of increased costs or category exclusivities $^{14}$.

Jerry C. Welsh, who in the 1980's was world marketing director for American Express, and who is considered by many to be the person who coined the term 'ambush marketing' ${ }^{15}$, suggests that it was precisely this closure to open sponsorship that led to ambush marketing: "Event organizers hope to sell their event-sponsoring wares at an auction among major intra-category competitors (...). Those companies who want to buy, or can afford to buy, often do buy; others must consider their marketing alternatives" 16 .

Many IP and sports law scholars agree that ambush marketing is a concept without a precise meaning or legal significance ${ }^{17}$, and therefore have trouble defining it. However, many refer to SANDLER and SHANI's (1989) approach to it, when suggesting that it occurs when a non-sponsor of an event attempts to pass itself off as an official sponsor in order to gain at least some of the recognition and benefits that are associated with being an official sponsor ${ }^{18}$. MeEnaGHAN (1994) developed this definition by stating that ambush marketing is "the practice whereby another company, often a competitor, intrudes upon public attention surrounding the event, thereby deflecting attention toward themselves and away from the sponsor" ${ }^{\prime \prime}$.

13. Ibid.

14. D. Crow and J. Hoek. "Ambush Marketing: A Critical Review and Some Practical Advice", in Marketing Bulletin, 2003, p. 2.

15. Johnson, P. 2008. Op. Cit., p. 8.

16. Welsh, J. Ambush Marketing: What is it, What isn't. Welsh Marketing Associates. Retrieved on December 2014 from [welshmktg.com/wMA_ambushmktg.pdf].

17. Wadlow, C. The Law of Passing-off: Unafair Competition by Misrepresentation. Sweet and Maxwell, London, 2011, p. 536.

18. Sandler, D and Shani, D. "Olympic Sponsorship vs. "Ambush" Marketing: Who Gets the Gold?", in Journal of Advertising Research, 1989, p. 11.

19. Meenaghan, T. "Ambush Marketing: Immoral or Imaginative Practice?”, in Journal of Advertising Research, 1994, pp. 77-88. 
Whatever the chosen definition, ambush marketing will occur when nonsponsors attempt to gain the benefits of brand exposure and awareness in a context that would otherwise be available only to official sponsors. Although ambush marketing is not limited to large-scale sporting events (v.gr. music festivals, radio broadcasts, cinema premiers, etc.), their extraordinary media coverage and the actions that have been taken against it make it the ideal scenario for discussion.

As mentioned in the introduction, the 1984 Olymplic Games in Los Angeles marked a cornerstone in the history of ambush marketing. JoHnson (2011) explains that during the late 1970's the International Olympic Committee's open policy on sponsorship (i.e. anyone who wanted to become a sponsor could arrange a deal) was not providing sufficient funds for hosting the Olympics, or even running the IOc. This lead to the newly elected President, Spanish Juan Antonio Samaranch, to transform the management of the Olympics by designing global sponsorship (and broadcasting) programmes, whose category-exclusive rights would be auctioned amongst interested parties. The new approach was implemented for the first time in the 1984 Games with three categories of Olympic Partners: official sponsor, official supplier and official licensee. The new tactic was deemed to be a financial success (it even created a surplus), so much so that it would later be followed by football's top governing body, FIFA.

By excluding non-sponsors from the former right to associate to the event, competitors of the Olympic Partners were forced to work around the newly-raised marketing barrier in order to benefit from the Games. As such, what are considered by some to be the first reported cases of ambush marketing occurred when Kodak failed to secure sponsorship rights for the 1984 Games to Fuji. Undeterred, Kodak became the sponsor of the ABC's broadcasts of those Games and the "official film" of the U.S. track team, thus working around the IOC's ban on non-sponsors associating to the Games -not the teams-. The other well noted case in the 1984 Games was when Converse, the official sponsor, was 'ambushed' by Nike, who built murals near the Olympic venues displaying its logo and Nike-sponsored athletes. The result was that $42 \%$ of consumers believed Nike to be an official sponsor ${ }^{20}$.

It goes beyond the purposes of this paper to go over the various kinds of ambush marketing campaigns. Besides, it would be pointless to do so since the practice itself calls for creative tactics that have no legal or practical limits: "There is no limit to human ingenuity. As such, ambush marketing at the margins will arguably always occur" ${ }^{21}$. However, on what many scholars agree on is that ambush marketing can take two forms: either direct, or indirect, and, if the latter, it can be indirect ambushing by association, or indirect ambushing by intrusion.

20. Fortunato, J. Sports Sponsorship: Principles and Practice. McFarland \& Co. Publishers. Jefferson, NC. 2013, p. 127.

21. Curthoys, J. and Kendall, C. Ambush marketing and the Sydney 2000 Games (Indicia and Images) Protection Act: A retrospective in Murdoch University Electronic Journal of Law, 8, 2001, Para. 8 . 
Direct (or 'blatant') ambush marketing occurs when a company or brand assertively correlates itself with an event when it has not made official payments or bought legal rights as the official sponsor ${ }^{22}$. This happens, for example, when there is "an intentional use of symbols and trademarks associated to the mass event so as to give consumers the wrong impression as to the actual sponsor of the event" ${ }^{\prime 2}$. This kind of ambushing occurred during the 2006 FIFA World Cup, when an U.S.-based non-sponsor internet company advertised offering commemorative coins bearing the inscription "2006 World Cup Germany", despite FIFA having registered the trademark "2006 World Cup". A much more delicate direct ambushing can occur by using advertisement stimuli -not a necessarily a protected distinctive sign-commonly used by sponsors so as to create the impression of being an official sponsor. Such would be the case of using jingles, imagery or footage from the event or its venues ${ }^{24}$.

Indirect (or 'subtle') ambush marketing, on the other hand, consists in "adjusting the message to the nature of the event in the manner which does not directly breach the rights of the organizers or the sponsors of the event, but rather uses the event as a pretext for the ambusher's own marketing purposes"25. As opposed to indirect ambushing, here ambushers use the event as an occasion or reason for their own marketing activities (brand awareness and exposure) without generating new, event-associated products ${ }^{26}$ such as the 2006 World Cup commemorative coins mentioned before.

Indirect ambush marketing tactics, in turn, are usually subdivided in two categories: Indirect ambushing by association, and indirect ambushing by intrusion. In the first case, the ambusher seeks to use the event as an "attention getter", exploiting it as a platform for communications, by means of direct or indirect references to the event. The main objective of indirect ambushing by intrusion, on the other hand, is to take advantage of the high spectator traffic and audience of massive events to conduct sales activities or brand awareness ${ }^{27}$. This type of ambushing involves "merely placing one's trademark or other indicia in event spaces where they will be captured by television cameras, or seen by those attending the event"28. One of the most famous ambushes falls under this classification: It occurred during the 2010 FIFA World Cup when 36 blonde models wearing orange mini-dresses bearing the logos of Dutch brewery Bavaria entered the stands at South Africa's Soccer City Stadium for the Netherlands vs. Denmark match. Predictably enough, the cameras turned towards them en masse, capturing shots that were transmitted

22. Shahira, A. Ambush Marketing; Are Sponsors Really Sponsoring?. Southern New Hampshire University, 2014. p. 3.

23. Louw, A. 2012. Op. Cit., p. 144.

24. Nufer, G. 2013. Op. Cit., p. 54.

25. Louw, A. 2012. Op. Cit., p. 5.

26. Nufer, G. 2013. Op. Cit., p. 54.

27. Ibid.

28. Scassa, T. "Ambush Marketing and the Right of Association: Clamping Down on References to That Big Event With All the Athletes in a Couple of Years", in Journal of Sport Management, 2011, p. 355. 
live all over the world, obviously irritating Anheuser-Busch, who had paid millions for Budweiser to be the official beer of the 2010 World Cup.

Whether ambush marketing is considered a legitimate business practice really depends on which side of the argument one falls in ${ }^{29}$. In his 1994 article titled "Ambush Marketing: Immoral or Imaginative Practice?" MEENGHAN asked whether ambush marketing was illegal or immoral, considering that few researchers have actually debated this question. Predictably enough, event organizers and official sponsors have regarded it as immoral because it threatens their ability to execute events or recoup investments made in these $\mathrm{e}^{30}$. From the perspective of the International Olympic Committee (IOC) or an Olympic Partner, ambush marketing is unethical with the potential to destroy sponsorship arrangements ${ }^{31}$. And as Asone corporate sponsor suggested, "Ambush marketing implies a connection to an event for which you have not compensated the owner. There's another word for it: stealing" 32 .

From the ambushers' perspective, instead, their advertising is a legitimate corporate practice, considering that their company participates in an important promotional opportunity that is often a heritage of the host city, whose access would otherwise be denied, therefore engaging in ambush marketing. Even a French Court ruling has taken a liberal view of ambush marketing campaigns as business opportunities in the public domain: "Sponsorship cannot deprive another economic player from basing its publicity on a sport (...). A sports event belongs to everyone because it constitutes part of current affairs and only its direct or televised showing can be the subject of specific rights acknowledged by article L.333-1 of the Code des Sports"33.

Whatever the case, the bottom line is that ambush marketing -whatever its kind- is characterised for being a practice that draws a commercial benefit from the reputation of a large-scale sponsored event, but without being an organizer, and without having to obtain the slightest authorization - payed or not- from organiz$\mathrm{ers}^{34}$. It is a true work-around to the advertisement barriers of official sponsorship that allow companies to exploit other's efforts to make large-scale events a reality; a sort of free-riding, where corporations pay millions for sponsorship rights, only to find competitors freeloading on the event. It is no wonder then that some say, with regards to ambush marketing, that "The threat to sponsorship dollars jeop-

29. Scassa, T. and Seguin, B. "Marketing Legislation to Protect the Olympic Sponsors: A Step Too Far in the Name of Brand Protection?", in Sport Management Review, 2011, p. 503.

30. D. Crow and J. Hoek. 2003. Op. Cit., p. 1.

31. J. Sebel and D. Gyngell, "Protecting Olympic Gold: Ambush Marketing and Other Threats to Olympic Symbols and Indicia", in UNSW Law Journal, 1999, p. 692.

32. B. Eтtorre. "Ambush Marketing: Heading Them Off at the Pass", in Management Review, 82, 1993, p. 55.

33. CA Paris, 10 févr. 2012, Cah. dr. sport n. ${ }^{\circ}$ 27, 2012, 247, cited in J. Marmayou, "Major Sports Events: How to Prevent Ambush Marketing?", in African Sports Law and Business Review, 2013, p. 42

34. Marmayou, J. 2013. Op. Cit., p. 47. 
ardises the financial viability of the sporting events" ${ }^{\prime 35}$. It is under this conviction that ambush marketing practices have been battled aggressively by event organizers.

\section{The Responses to Ambush Marketing Practices}

Sponsors and event organizers have adopted a variety of strategies to prevent ambush marketing. Interestingly, however, their response has been usually far from a legal one. This is often explained by the practical risks that legal actions imply: The undeveloped legal status of ambush marketing practices necessarily leads to an uncertain lawsuit outcome, thus possibly forging unwanted precedents, and the reluctance to alienate potential sponsors in the future by suing them. As such, some suggest that non-legal strategies "may be the most effective way of protecting oneself from such activity" 36 .

The range of non-legal and commonly suggested marketing strategies call for official event sponsors to compete with their own advertisements. For example, event organizers can control the billboards around the event by buying up the space for their sponsors only. This even led the International Olympics Committee to announce in 1997 that any city bidding to host the Olympics had to secure all advertisement space within city limits for official sponsors only, for the entire month in which the Games were to be held ${ }^{37}$. Similarly, sponsors can buy up advertisement slots on the networks televising the event, thus keeping non-sponsoring competitors from buying that time to ambush the event. Other strategies that are commonly employed are for event organizers and sponsors to hire personnel to monitor and enforce ticketing restrictions (e.g. prohibitions to resell or be given away as prizes on promotions by non-sponsoring competitors, unauthorized display of competing brands -intrusions-, etc.) or to invest in public education-via television, newspaper ads or mass mailings- to prevent or lessen the impact of ambush marketing (e.g. convincing the public that advertising activity that appears to be wrongfully associating to the event is actually threatening it).

All of these essentially marketing-oriented strategies to combat ambush marketing, however, call for both event organizers and official sponsors to spend even more money to secure the exclusive rights to associate to the event. It is hard to understand that after paying an over $\$ 40$ million fee, a sponsor would be advised to buy additional media time or advertising spaces around event venues to exclude competing ambushers. Meenaghan (1998) points out the need for sponsors to purchase mass media time and space to promote their sponsorship, but simultaneously suggested that sponsors may need to spend two to three times the cost of the sponsorship rights to promote their association with an event ${ }^{38}$. Similarly, for cities

35. Sebel, J. and D. Gyngell. 1999. Op. Cit., p. 392.

36. Vasallo, E.; K. Blemaster and P. Werner. "An International Look at Ambush Marketing”, in Intellectual Property Journal, 2005, p. 100

37. Ibid.

38. Meenaghan, T. "Current developments and future directions in sponsorship", in International Journal of Advertising, 17, 1998. 
to assure that all advertising spaces would be reserved for official sponsors only, would rule out economic competition for the spots, therefore annulling the real market-cost of such spaces (without demand, prices would fall) ${ }^{39}$ limiting financial profit. As such, these strategies are definitely not what sponsors or event organizers want to hear, and have therefore had to rely on traditional and extraordinary legal means, with the difficulties and issues that they raise, especially considering that there is no legal protection for events as such ${ }^{40}$.

Intellectual Property Law (trademark, copyrights, industrial designs, etc.) is the defense instrument that the victims of ambush marketing first turn to and it is the first recourse that comes to mind due to the worldwide harmonization that characterizes this body of law, for a cross border phenomenon ${ }^{41}$. Under the Paris Convention for the Protection of Industrial Property of 1883, all member States are required to provide protection for trademarks, services marks, trade names, indications of source or appellations of origin, and effective means for the repression of unfair competition, amongst others. Similarly, the Berne Convention for the Protection of Literary and Artistic Works of 1886 calls for protection of copyrights. Considering that as of January of 2015 the Paris Convention had 176 contracting parties, and Berne Convention's 168 contracting parties, all intellectual property and unfair competition laws deriving from these two treaties provide a minimum international, nearly world-wide standard for protecting sponsors and event organizers from ambush marketing practices that involve unauthorized use of their imagery. Event organizers are therefore generally encouraged to obtain IP protection for relevant material such as emblems, logos, anthems, official mascots, etc., through trademark or copyright protection ${ }^{42}$. FIFA, for instance, has prioritized its programme to register trademarks and otherwise protect the IP rights in its logos, emblems, etc., now holding over 700 mark protection entries in 134 countries for the FIFA World Cup Trophy -the most recognizable sporting trophy in the world-, alone ${ }^{43}$.

In the case of the Olympics, this IP-focused approach is privileged and it is further reinforced by Paris Convention's article 6 ter provision requiring protection for the emblems of certain international organizations, as well as the Nairobi Treaty on the Protection of the Olympic Symbol of 1981. Under the Nairobi Treaty, all party States are under the obligation "to refuse or to invalidate the registration as a mark and to prohibit by appropriate measures the use (...) of any sign consisting

39. Such was the case of Athens hosting the 2004 Olympic Games, who agreed to secure all advertising spots within city limits, despite the $\$ 10$ million worth of revenue it was expected to cost the city. Vasallo et. al. 2005, Op. Cit., p. 100.

40. Johnson, P. 2008. Op. Cit., p. 4.

41. Marmayou, J. 2013. Op. Cit., p. 43.

42. Louw, A. 2012. Op. Cit., p. 125.

43. Ibid. 
of or containing the Olympic symbol" -the five interlaced rings- for commercial purposes, without the authorization of the International Olympic Committee ${ }^{44}$.

However, this traditional IP approach has been considered by event organizers and their sponsors as unsuccessful -or at least insufficient- to fully eradicate ambush marketing for several reasons. Firstly, the relationship between ambushers and event organizers does not correspond to the conventional trademark infringement or unfair competition claims framework required in some jurisdiccitions (for instance Brazil, Germany and Austria ${ }^{45}$ ), in which a competitive relationship is needed between plaintiff and defendant for a likelihood of confusion to be actually caused -e.g. it is a well known fact that FIFA does not compete directly with Nike in the sports apparel market-. This is equally challenging for a cause of action on unfair competition grounds because ambushes are rarely considered to be conducts that are likely to confuse or deceive consumers as to the source of goods and services (as provided by the Paris Convention), nor are they suitable to deflect clientele from the event itself.

In addition to the above mentioned difficulties, the protection of the relevant event material, especially the event name, poses a trademark law challenge on itself. Tradition has led major events to be named under "City+Year" identifiers, such as the "Rio 2016" Olympics or the "Brazil 2014" fifa World Cup. However, the distinctive character of a trademark composed of a city and a year is commonly challenged. Such was the case of FIFA's failed attempt to register "Fussball WM 2006" and "WM 2006" in Germany insofar as both the German Trademarks Office and the Supreme Court regarded these signs as mere descriptions of the event and hence not capable of trademark protection. The same rationale led the Delhi High Court to refuse registration for the marks "World Cup" and "Cricket World Cup" ${ }^{36}$.

But even if major event organizers were to succeed in protecting their imagery, the fact is that "as currently conceived, trademark law, even in its most expansive form, simply does not cover ambush marketing methods which do not employ protected trademarks" ${ }^{\prime 7}$. While the unauthorized use of a registered trademark may constitute a straightforward infringement, except from few direct ambushes, marketers do not usually use third parties' marks. Marmayou (2013) goes as far as saying that "To use or imitate the trademark or the logo of another is a stupid and malicious

44. World Intellectual Property Organization. Nairobi Treaty on the Protection of the Olympic Symbol, adopted at Nairobi on September 26, 1981.

45. LIDC, Rapport international sur la question $B$ : le marketing sauvage est-il trop beau pour être honnête? Faudrait-il déclarer certaines pratiques de marketing sauvage illégales, et si oui, lesquelles et sous quelles conditions? Available at: [www.ligue.org/fr/homepage/].

46. Marmayou, J. 2013. Op. Cit., p. 43.

47. Ericsson, S. Ambush Marketing: Examining the Development of an Event Organizer Right of Association, in N. LeE, et al. (ed.), Intellectual Property Unfair Competition and Publicity, Edward Elgar Publishing, Cheltenham, UK / Northampton, MA, 2014, p. 172. 
infringement of intellectual property rights. It is not ambush marketing”. Instead, ambush marketing campaigns creatively refer to an event using their own marks and trade names to associate themselves with it (v.gr. indirect ambush marketing, $u t$ supra), or cleverly working around the scope of protection of the event trademarks. Consider for instance how a few months prior to the 1996 Olympics Telecom New Zealand -a non-sponsor- ingeniously used the word "ring" as a play of the ringing of a telephone, and used it in the following visual arrangement, claiming that "With Telecom Mobile, you can take your own phone to the Olympics":

\section{RING RING RING RING RING}

In this case, the New Zealand Olympics and Commonwealth Games Association (NZO\&CWA) sought interim injunction prohibiting Telecom from airing the ad, claiming forgery of the five interlocking rings trademark (the Olympic symbol), amongst others. The injunction, however, was declined because the visual devise was considered too different form the Olympic symbol to create a significant likelihood of confusion or association to the Olympics ${ }^{48}$.

Clever ambushers will go as far as using claims that explicitly rule out any likelihood of confusion, as the South African airline Kulula Airways did during the 2010 FIFA World Cup, using the slogan "The unofficial national carrier of youknow-what" accompanied by football images. By doing this, they kept away from any claim of trademark infringement, misappropriation, false and/or misleading advertising, but obviously succeeding in irritating FIFA and its sponsors.

As a result, a Paris Convention trademark or unfair competition approach remedy is often unavailable to the ambushed party, simply because smart "[a] mbush marketing is not a 'classic form of trademark infringement in products and services.' (...) When narrowly defined, ambush marketing does not fall within the reach of traditional trademark law-oriented and unfair competition-based causes of action" ${ }^{39}$. This challenge can only push major event organizers and -powerfulsponsors to lobby for extraordinary legal means to combat ambush marketing, namely through the adoption of ad-hoc or tailor-made event specific legislation that extends the protection provided by the minimum standards of the Paris Convention, or through straightforward anti-ambush marketing legislation.

A common trend in sports today is for sport governing entities to place a requirement on the local governments hosting the events to enact specific legislation to

48. Hoek, J. “"Ring Ring': Visual Pun or Passing Off?: An Examination of Theoretical and Research Issues Arising from Ambush Marketing”, in Asia-Australia Marketing Journal, 6, 1997, pp. 35-36.

49. Ericsson, S. 2014. Op. Cit., p. 173. 
protect the event's imagery and the interests of its official sponsors. Since the 2000 Sydney Olympics, for instance, the International Olympic Committee demands specific legislation (aside from adherence to the Nairobi Treaty, of course) to protect the Games against unauthorized commercial exploitation. This strategy has been followed by equally powerful organizations such as UEFA and FIFA ${ }^{50}$. Indeed, the enactment of such laws has become a de facto condition for hosting the Olympics or any other sporting mega-event, raising awareness as to the enormous power that event organizers have on public policy of hosting cities or countries. As has been aptly put, we are confronted here with "the manipulation of governments by sports organizations that make enactment of event-specific legislation a 'cost of doing business' in exchange for hosting the event, practically forcing bidding cities or countries to comply to such demands in order to qualify to be awarded the hosting rights" 51 . This strategy can be labelled "host city obligations".

In light of the above, several countries have enacted legislation for the Olympic Games, such as China (Regulations on the Protection of Olympic Symbols), Greece (Protection of the Olympic Symbol), Italy (Turin Olympics Act) and Australia (Sydney 2000 Games Protection Act 1996), but other events have called for adoption of event-specific legislation, such as the South Africa 2003 Criket World Cup (later updated for the 2010 FIFA World Cup), the 2006 Melbourne Commonwealth Games and UefA's Portugal euro 2004 ${ }^{[52]}$. All these laws fall somewhere between the trademark and unfair competition laws of said countries, as they all tend to guarantee that no company shall mislead and confuse the public into believing that the company was approved and/or authorized by any organizing committee to associate to the event. They are therefore deemed as an expansion of industrial property and unfair competition laws.

However, it was the passing of the London Olympic Games and Paralympics Games Act of 2006 (2006 Act) that targeted ambush marketing directly, creating the so-called "London Olympics Association Right" (LOAR), a right created to specifically address the irritating non-sponsor advertising activities not previously covered by trademark or unfair competition law ${ }^{53}$. In other words, the 2006 Act intended to prevent a specific type of advertising activity by establishing a presumption that the use of the following expressions will infringe the LOAR: "games", "two thousand and twelve", "2012", "twenty twelve"; and any combination of the former expressions with any of the following expressions: "gold", "silver", "bronze", "medals", "London", "sponsor" and "summer". As such, the 2006 Act provides a trademark-like protection to the holder of the LOAR, even though terms such as "games" or "summer" would not be customarily granted trademark protection due

50. Louw, A. 2012. Op. Cit., p. 163.

51. Ibid.

52. Johnson, P. 2008. Op. Cit., p. 16.

53. Ericsson, S. 2014. Op. Cit., pp. 178-186. 
to their lack of distinctive character ${ }^{54}$. Under such steep provision, an apparently harmless slogan such as "Spend the 2012 summer in London" would be presumed to infringe the LOAR, potentially impacting freedom of [commercial] expression. This last issue will be addressed afterwards.

A second manifestation of the creation of special legal protection to the rights to events relates to the extension of "safe heaven" areas for issues of security, infrastructure readiness (e.g. adequate public transportation to the venues, suitable airports and train stations, etc.) and guaranteed public interest (i.e. full stadia, adequate media coverage, etc.), to actual commercial rights protection, on what is known as "clean zones" or "marketing exclusion zones" for event venues and their surroundings. These are required by IOC and FIFA events, as well as for the American Super Bowl. As McKelvey and Grady (2008) explain,

Event organizers are increasingly using the host site bid process to ensure that countries and cities enact special legislation establishing 'clean zones'. Although ordinances establishing clean zones are publicly positioned by event organizers as a means of controlling excessive commercialism (and sometimes providing for public safety), the underlying purpose is to protect event organizers and their official sponsors from unauthorized business' ability to engage in ambush marketing. (...) Among other application requirements, the 'Candidate City' must demonstrate that it has 'obtained unconditional commitments from all public or private entities (e.g. government authorities, advertising space owners, etc.) within the territory, to protect the Olympic image and prevent ambush marketing 55 .

In its bid package for potential Super Bowl host cities, for example, the American National Football Association (NFL) requires that the host cities enact an ordinance prohibiting "temporary signs, inflatables and buildings wrapped with advertising banners" in an area covering a one mile radius around the stadium site during Super Bowl week, thus controlling ambush marketing by intrusion. Additionally, the bid package recommends that the ordinance give the NFL the discretion to approve or deny requests for such temporary signage otherwise prohibited under the clean-zone ordinance ${ }^{56}$.

Just like the traditional Paris Convention-oriented remedies to ambush marketing face insufficiency issues, the above-mentioned extraordinary means, in its two forms -i.e. event specific-legislation that expands trademark and unfair competition laws, and event-specific legislation that expands clean zones to commercial rights protection-, face hard to answer constitutionality questions.

54. Ibid.

55. Grady, J. and McKelvey, S. "Sponsorship Program Protection Strategies for Special Sport Events: Are Event Organizers Outmaneuvering Ambush Marketers?”, in Journal of Sport Management, 2008.

56. Sliffmann, A. "Unconstitutional Hosting of the Super Bowl: Anti-Ambush Marketing Clear Zones' Violation of the First Amendment", in Marquette Sports Law Review, 2011, pp. 273-274. 
Firstl, it is clear that the adoption of event-specific legislation is in most cases the result of a bidding process in which there are tailor made law-making obligations imposed by the event organizers, in exchange for the hosting rights. This clashes, on itself, with the principle of legality according to which laws are meant to be general and abstract, and not aimed at protecting the rights or interests of specific entities such as sports events organizers and their commercial partners exclusively (i.e. a law cannot be made for a single case, and in benefit of a single party). Equality principles may also be breached by granting protection over descriptive terms that would otherwise be non-registrable to third parties due to their lack of distinctiveness, thus withdrawing them from public domain, in violation of IP treaties. Additionally, on countries that have a constitutional provision for a free market economy, and the right to conduct free enterprise and/or to compete freely in the marketplace, the manipulation of governments by sports organizations to adopt host site obligations can be seen as an abusive exercise of market power. In the end, event organizers and their commercial partners are true undertakings that enjoy a dominant position for their specific sporting events, and can use that power to get legislators to back it up. This explains suggestive titles for in-depth ambush marketing studies such as Andre M. Louw's comprehensive work "Ambush Marketing \& the Mega-Event Monopoly: How Laws are Abused to Protect Commercial Rights to Major Sporting Events".

Free speech and private property are also constitutional barriers that eventspecific legislations must overcome. As mentioned when addressing the London Olympic Games and Paralympics Games Act of 2006, an apparently harmless slogan such as "Spend the 2012 summer in London" would be deemed to infringe the London Olympic Association Right (LOAR) for using three terms banned to non-sponsors. The impact of such a limitation seriously impacts commercial free speech and becomes even more questionable when the use of certain expressions is subject to approval by a private entity, rather than by public authorities. The same applies to private property and the clean zones approach; although aesthetics and safety may by considered legitimate ends for limiting the use of private property and commercial free speech, provisions providing discretion to a private-sector company to authorize its use in the public forum -such a the one required in the NFL bid package- will and should be found unconstitutional, for their particular commercial interest is certainly not a legitimate end.

In is clear therefore that $a d$ hoc anti-ambush marketing laws -i.e. event-specific legislation- face intense scrutiny on constitutional grounds, and that is why there have been pushes for policy control. In fact, two of the largest and most significant IP-related non-governmental organizations -the Association Internationale pour la Protection de la Propriété Intellectuelle (AIIPI) and the International Trademark Association (INTA)- have adopted resolutions on how policy on ambush marketing should be approached. 
On October 2009, AIIPI adopted Resolution Q210 on "The protection of major sports events and associated commercial activities through Trade Marks and other IPR" ${ }^{\prime}$. The resolution noted that international sports governing bodies award the right to host major sports events to a country or city "after a tender process which requires the bidding country or city to give certain commitments" that include creating "sui generis exclusive rights" which can be licensed or awarded to official sponsors (e.g. the LOAR in the London 2006 Act). Those sui generis rights created by virtue of host city commitments - points out the Resolution-supplement trademark and unfair competition law. However, they "lead to an increasing divergence of intellectual property law at a regional or even global level".

But what was truly constructive on AIPpI's Resolution was noting that "It is necessary to balance the interests of sponsors and international sports governing bodies with the interests of the public, non-sponsor businesses, governments and any other parties affected by the creation and award of exclusive rights", considering that -on the other hand- the international trademark and unfair competition regime had succeeded in developing general and well-established principles that do aim to protect the interests of all relevant parties in the marketplace. As such, AIPPI resolved that (1) trademark and unfair competition laws should not be amended just for major sports events, (2) sui generis rights for major sports events that extend trademark and unfair competition laws should be avoided, and, acknowledging the fact that these laws will continue to exist on account of the pressures from international sports governing bodies, (3) whenever sui generis rights are created, they should provide a balance between the interests of all relevant parties by a) being limited in time around the event, $b$ ) only be infringed where an unfair advantage results from the association to the event, c) only be infringed by commercial activities, and c) be subject to a balancing of interests with the right to freedom of [commercial] expression.

Like AIPPI before it, the Board of INTA adopted a resolution ${ }^{58}$ on ambush marketing legislation on November 2010. It acknowledged as did Resolution Q210 that "the intense competition to become the host country for major events increasingly has led to the enactment of special legislation to prevent ambush marketing for such events". However, unlike AIPPI, INTA's Resolution did not frown upon adopting anti-ambush marketing legislation or creating sui generis exclusive rights, but rather recommended that "countries electing to adopt ambush marketing legislation relating to major events ensure that the legitimate rights of trademark owners and the public to use trademarks and descriptive terms fairly are balanced appropriately against the rights of event sponsors and organizers". To accomplish

57. Association Internationale pour la Protection de la Propriété Intellectuelle (AIIPI). Resolution Q210 of October 14, 2010, adopted in Buenos Aires, Argentina. Available at: [www.aippi.org/download/commitees/210/RS210English.pdf].

58. International Trademark Association. Sponsoring Committee: Emerging Issues Committee. Resolution of November 10, 2010. Available at: [www.inta.org/Advocacy/ Pages/AmbushMarketingLegislation.aspx]. 
this, INTA recommended, among other guidelines, that prior to adopting ambush marketing legislation for the protection of a major event, event emblem or word, there should be consultation with potentially affected parties.

Although AIPPI's adverse position on anti-ambush marketing legislation contrasts with INTA's favourable-but-balanced view, both resolutions suggest some agreeing assumptions: The fact that both organizations call for balancing ambush marketing legislation, implies that (i) they have already taken a negative posture on it (i.e. that it is a harmful -if not an illegal- practice against the events, their organizers and sponsors) by accepting that something must be done about it, but that (ii) nonetheless, the repression of ambush marketing unfairly threatens e.g. the freedom of [commercial] expression of third parties, on a manner way more troublesome that traditional trademark and/or unfair competition laws do. It also implies that both organizations believe that (iii) international sports governing bodies are over empowered to trace public policy on this matter, and that (iv) there is an urgent need to harmonize, at an international level, the legal framework for it.

\section{Conclusions}

Whether ambush marketing is unethical, illegal or foul-play, or if it is smart, savvy advertising is a question that has been left for scholars to mull over academically, because the market power of mega event organizers over host site governments has clearly placed the law on the against-it shore of the debate, thus settling it on a pragmatic point of view: Mega event organizers will simply not risk the event's financial viability and profit if proper protection is not given to the event's imagery and their sponsors. This approach, however, rises what is pointed out as the ambush marketing paradoxes:

1. Mega sporting events such as the Olympics and the FIFA World Cup are, in theory, essentially universal events for both participants and spectators. This explains the millions invested in marketing them, making them happen and broadcasting them all over the world. It is ironic, however, that the sponsors' substantial contribution to make them a reality is preferably rewarded by a completely opposite rationale: By excluding other parties that may also identify themselves with the values of a current affair of public interest.

2. Ambush marketing is a phenomenon that occurs more prominently in sporting events, where competition is precisely what is desired to make them interesting and exciting. Ironically, it is exactly in this competing context that marketing and advertisement competition is refused. It could be argued that ambush marketing, when used properly, is merely another way for companies to compete in ingenuity and advertising skills, but the exclusive right of association rules it out.

3. The values that mega sporting events embody are usually of a "fair play" nature. Ironically, cases such the Bavaria Girls mentioned before, lead to authorities arresting fans and pressing charges against event supporters and spectators without 
consideration of "fair uses", ultimately alienating them from event organizers and their sponsors. The effects of this negative perception may result more damaging to sponsors than the millions invested by them. The shift from the athletic competition to the off-field corporate rivalry for exclusivity does not go unnoticed by fans, who see how sports are slowly (or rapidly) drifting away to become the stadia for corporate legal battlefields.

4. Mega sporting events are huge business opportunities and offer potential economic booms for host sites by promoting and attracting tourism and consumption. However, ironically, the urge to restrict the right of association to the event makes it difficult, if not impossible, for non-sponsoring hotels, restaurants, public utilities companies, etc., -who are the vast majority of the resulting trade- to capitalize on a most likely once-in-a-lifetime business opportunity. This is further worsened by the fact that without the indirect support of these industries, which welcome and host spectators, the events would be a complete failure.

5. Considering that marketing and advertisement are inherently creative activities, it is ironic that the more repression ambush marketing gets, the more incentive for marketing ingenuity is needed to work around it, ultimately prompting advertisers to come up with new, unexpected and unforeseen campaigns that will continue to make anti-ambush marketing legislation insufficient.

These paradoxes, along with the inherent difficulties of legally challenging the adverse effects of the ambush marketing phenomenon, call for an urgent, international consensus of means for treating it properly, considering the freedom of commercial expression, fair use and the legitimate commercial activities of non-sponsors. As with all other forms of intellectual property, the question of contrasting ambush marketing lays in reaching a balance between the monopoly and the public domain of a privately organized and sponsored mega event that belongs to everyone, since they are no more than sporting spectacles that constitute part of current affairs.

\section{BIBLIOGRAPHY}

Crow, D. and J. Hoek. "Ambush Marketing: A Critical Review and Some Practical Advice", in Marketing Bulletin, 2003.

Curthoys, J. and C. Kendall. "Ambush marketing and the Sydney 2000 Games (Indicia and Images) Protection Act: A retrospective", in Murdoch University Electronic Journal of Law, 8, 2001.

Ericsson, S. "Ambush Marketing: Examining the Development of an Event Organizer Right of Association", in N. LeE et al. (ed.), Intellectual Property Unfair Competition and Publicity, Edward Elgar Publishing Ltd., Cheltenham, UK / Northampton, MA, 2014, pp. 165-188.

Fortunato, J. Sports Sponsorship: Principles and Practice. McFarland \& Co. Publishers. Jefferson, NC, 2013, p. 127. 
Grady, J. and S. McKelvey. "Ambush Marketing: The Legal Battleground for Sport Marketers", in Entertainment and Sports Lawyer, 2004, pp. 8-14.

Grady, J. and S. McKelVey. "Sponsorship Program Protection Strategies for Special Sport Events: Are Event Organizers Outmaneuvering Ambush Marketers?”, in Journal of Sport Management, 2008, pp. 397-445.

Hoek, J. '“Ring Ring': Visual Pun or Passing Off?: An Examination of Theoretical and Research Issues Arising from Ambush Marketing", in Asia-Australia Marketing Journal, 6, 1997, pp. 35-36.

Johnson, P. Ambush Marketing and Brand Protection: Law and Practice. Oxford University Press, New York City, 2011, pp. 3-25.

Kalamadi, S. "Intellectual Property and the Business of Sports Management", in Journal of Intellectual Property Rights, 2012, pp. 437-442.

Kim, J. W. "The worth of Sport Event Sponsorship; An Event Study", in Journal of Management and Marketing Research, 2010.

KuR, A. et al., "Intellectual property, unfairness and speech - convergences and development”, in N. LeE, et al. (ed.), Intellectual Property Unfair Competition and Publicity, Edward Elgar Publishing, Cheltenham, UK / Northampton, MA, 2014, pp. 1-7.

Louw, A. Ambush Marketing \& the Mega-Event Monopoly. How Laws are Abused to Protect Commercial Rights to Major Sporting Events. T.M.C. Asser Press. The Hague, 2012.

Marmayou, J. "Major Sports Events: How to Prevent Ambush Marketing?”, in African Sports Law and Business Review, 2013.

Meenaghan, T. "Ambush Marketing: Immoral or Imaginative Practice?", in Journal of Advertising Research, 1994, pp. 77-88.

Meenaghan, T. "Current Developments and Future Directions in Sponsorship", in International Journal of Advertising, 17, 1998.

Nufer, G. Ambush Marketing in Sports: Theory and Practice. Routledge, New York, 2013.

Sandler, D. and Shani, D. Olympic Sponsorship vs. "Ambush" Marketing: Who Gets the Gold?, Journal of Advertising Research, 1989, p. 11.

SCassa, T. "Ambush Marketing and the Right of Association: Clamping Down on References to That Big Event With All the Athletes in a Couple of Years", in Journal of Sport Management, 2011.

Sebel, J. and D. Gyngell. "Protecting Olympic Gold: Ambush Marketing and Other Threats to Olympic Symbols and Indicia", in UNSW Law Journal, 1999, pp. 691-707.

Seguín, B. and T. Scassa. "Ambush Marketing Legislation to Protect the Olympic Sponsors: A Step Too Far in the Name of Brand Protection?", in Sport Management Review, 2011, pp. 297-308.

Shahira, A. Ambush Marketing; Are Sponsors Really Sponsoring? Southern New Hampshire University, 2014, pp. 3-8. 
Sliffmann, A. "Unconstitutional Hosting of the Super Bowl: Anti-Ambush Marketing Clear Zones' Violation of the First Amendment", in Marquette Sports Law Review, 2011.

Vasallo, E.; K. Blemaster and P. Werner. "An International Look at Ambush Marketing", in Intellectual Property Journal, 2005, pp. 87-102.

WaDlow, C. The Law of Passing-off: Unafair Competition by Misrepresentation. Sweet and Maxwell, London, 2011, p. 536.

Welsh, J. Ambush Marketing: What is it, What isn't. Welsh Marketing Associates. Retrieved on December 2014 from [http://welshmktg.com/wMA_ambushmktg.pdf]. 